\title{
Some Ancestral Caddo Sites on Bayou Loco in the Angelina River Basin, Nacogdoches County, Texas
}

Timothy K. Perttula

Heritage Research Center, Stephen F. Austin State University

Follow this and additional works at: https://scholarworks.sfasu.edu/ita

Part of the American Material Culture Commons, Archaeological Anthropology Commons, Environmental Studies Commons, Other American Studies Commons, Other Arts and Humanities Commons, Other History of Art, Architecture, and Archaeology Commons, and the United States History Commons

Tell us how this article helped you.

This Article is brought to you for free and open access by the Center for Regional Heritage Research at SFA ScholarWorks. It has been accepted for inclusion in Index of Texas Archaeology: Open Access Gray Literature from the Lone Star State by an authorized editor of SFA ScholarWorks. For more information, please contact cdsscholarworks@sfasu.edu. 
Some Ancestral Caddo Sites on Bayou Loco in the Angelina River Basin, Nacogdoches County, Texas

\section{Creative Commons License}

\section{(c) (1) \&}

This work is licensed under a Creative Commons Attribution-NonCommercial 4.0 International License 


\section{Some Ancestral Caddo Sites on Bayou Loco in the Angelina River Basin, Nacogdoches County, Texas}

\section{Timothy K. Perttula}

\section{INTRODUCTION}

Archaeological research has been ongoing since the 1930s along Bayou Loco in the western part of Nacogdoches County in the East Texas Pineywoods (Figure 1). Bayou Loco is a southward-flowing tributary to the Angelina River.

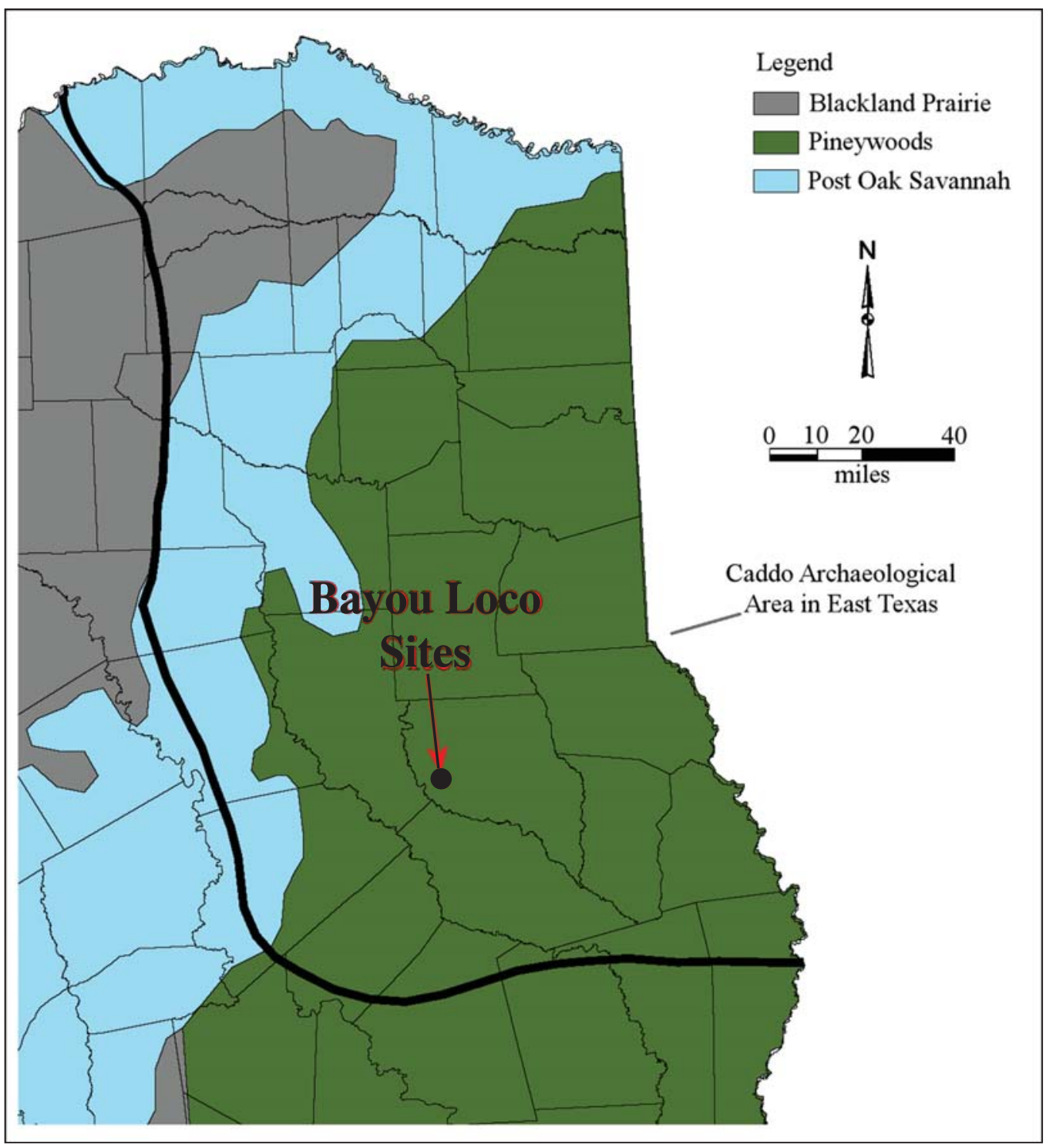

Figure 1. Location of the Bayou Loco sites in the East Texas Pineywoods. 
Jackson et al. (2012:120) note that it was the proposed construction of the Bayou Loco Reservoir (Lake Nacogdoches) in 1972 that led to an important surge in the extent of archaeological research along Bayou Loco, beginning with an archaeological survey (Prewitt et al. 1972), followed up by excavations at several sites that would be inundated by the lake, principally the Mayhew site (41NA21; see Kenmotsu 1992; Jackson et al. 2012:195-208) and the Deshazo site (41NA13/27) (Story 1982, 1995). The Deshazo site's Caddo cemetery had been found and excavated by R. L. Turner, Sr. and R. L. Turner, Jr. in 1937, and successful University of Texas (UT) Field Schools led by Dr. Dee Ann Story in 1975 and 1976 uncovered substantial evidence of an historic Caddo farmstead at the expansive site along Bayou Loco (see Good 1982; Story and Creel 1982).

The sites discussed herein are along Bayou Loco and they have been inundated by the waters of Lake Nacogdoches. They were either recorded by Thomas Mayhew, an art teacher at Stephen F. Austin State University in Nacogdoches, Texas, or by Prewitt et al. (1972) during their survey of then proposed Lake Nacogdoches.

\section{SITES}

\section{NA19, Pleasant Hill Site}

The Pleasant Hill site is on an upland ridge on the west side of Bayou Loco that projects into the Bayou Loco floodplain. The site is estimated to cover about 3 acres of the ridge. Archaeological materials from the site in the collections at the Texas Archeological Research Laboratory at The University of Texas at Austin (TARL) are from 1972 survey work, a single test pit, and a small collection donated to TARL by Tom Middlebrook in 1978.

The collections from the Pleasant Hill site include a petrified wood Yarbrough dart point, indicative of Late Archaic use, and a single body sherd of Goose Creek Plain, var. unspecified. This ceramic ware is associated with Woodland period cultures in the southern part of East Texas, and is evidence that the site was occupied sometime during the Woodland period, between ca. 500 B.C. and A.D. 800 (see Ellis 2013; Perttula 2013).

The archaeological materials from the ancestral Caddo component at the site consist of 195 ceramic sherds from plain ware $(n=144)$, utility ware $(n=45)$, and fine ware $(n=6)$ vessels. These vessels are tempered with grog (80 percent) or bone (20 percent).

More than 55 percent of the decorated sherds from the Pleasant Hill site are from vessels, likely Bullard Brushed jars, with brushed, brushed-punctated, or brushed-appliqued decorative elements (Table 1). This suggests a Caddo occupation that took place after the $15^{\text {th }}$ century A.D., given the high frequency of brushed sherds in Late Caddo utility wares in the Angelina River basin. Sherds with incised decorative elements account for 18 percent of the decorated sherds, and 14 percent of the decorated sherds are from vessels with punctated decorative elements. Only 12 percent of the decorated sherds from the site are from engraved fine wares.

Table 1. Decorated sherds from the Pleasant Hill site (41NA19).

Decorative method/

Rim

Body

$\mathrm{N}$

decorative element

Utility Ware

Appliqued

large appliqued node

1

1 
Table 1. Decorated sherds from the Pleasant Hill site (41NA19), cont.

\begin{tabular}{llll}
\hline $\begin{array}{l}\text { Decorative method/ } \\
\text { decorative element }\end{array}$ & Rim & Body
\end{tabular}

\section{Brushed}

parallel brushing marks

$\begin{array}{lll}- & 26 & 26 \\ - & & \\ & 1 & 1\end{array}$

\section{Brushed-Appliqued}

parallel brushing and straight appliqued ridge

\section{Brushed-Punctated}

parallel brushed-tool punctated rows through

$-$

the brushing

\section{Incised}

cross-hatched lines

curvilinear lines

opposed lines

parallel lines

straight line

$\begin{array}{ccc}- & 1 & 1 \\ & & \\ - & & \\ - & 1 & 1 \\ - & 1 & 1 \\ - & 1 & 3 \\ - & 3 & 3\end{array}$

\section{Punctated}

single cane punctation

single fingernail punctate

fingernail punctated rows

tool punctated rows

$\begin{array}{lll}- & 1 & 1 \\ - & 1 & 1 \\ - & 3 & 3 \\ - & 2 & 2\end{array}$

Fine Ware

\section{Engraved}

diagonal lines, R-L

diagonal opposed lines and triangle el.

diagonal opposed hatched zones

opposed lines

parallel lines

straight line

Totals

1

\begin{tabular}{lll}
1 & - & 1 \\
- & 1 & 1 \\
- & 1 & 1 \\
- & 1 & 1 \\
- & 1 & 1 \\
- & 1 & 1 \\
\hline
\end{tabular}

$\mathrm{R}-\mathrm{L}=$ right to left; the engraved lines begin at the right at the top of the rim and end at the left at the bottom of the rim

The engraved fine ware sherds feature geometric elements, including sets of diagonal lines on a rim panel, as well as a body sherd with diagonal opposed engraved lines (Figure 2b). A grog-tempered sherd from a bottle has diagonal opposed hatched zones (Figure 2a). 


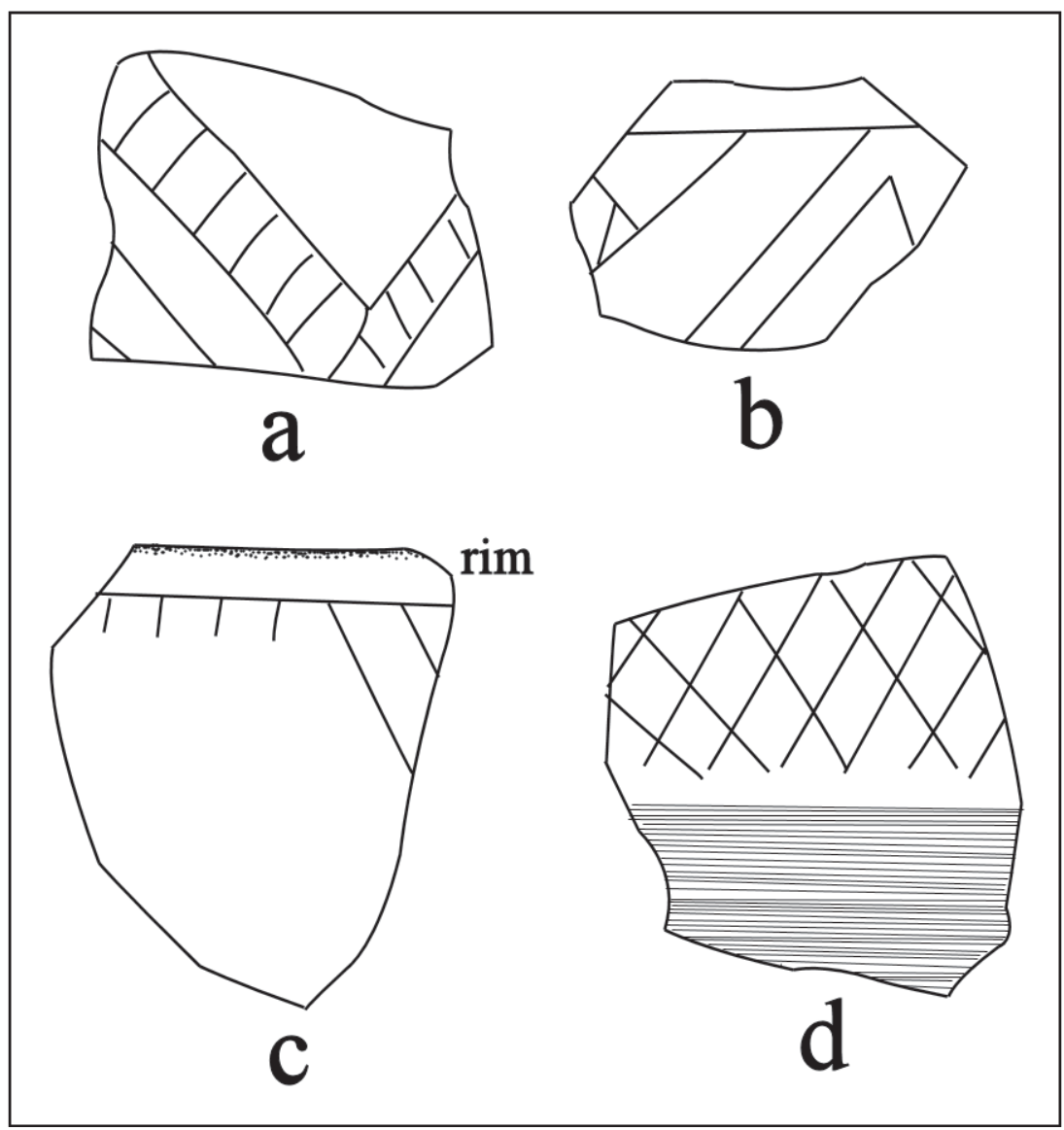

Figure 2. Selected decorative elements in the fine ware sherds from Bayou Loco sites: a-b, 41NA19; c, 41NA26; d, 41NA29.

\section{NA20, Riser Site}

The Riser site is on a small (ca. 0.6 acres) natural rise in the Bayou Loco floodplain, on the west side of Bayou Loco. In addition to 1972 survey work by Prewitt et al. (1972), 14 backhoe trenches and a single test pit were excavated at the site in April 1975 by UT archaeologists.

There may have been a substantial Woodland period occupation at the Riser site. The site collections include a petrified wood Gary dart point of that age and 30 rim and body sherds from Goose Creek Plain, var. unspecified vessels.

The ancestral Caddo occupation at the site includes six pieces of daub and burned clay - likely remnants of a burned Caddo wood structure - and 185 sherds from plain ware $(n=109)$, utility ware $(n=72)$, and fine ware $(n=4)$ vessels. About 86 percent of the sherds are from grog-tempered vessels and the remaining 14 percent are from bone-tempered vessels.

Sherds from utility ware vessels dominate the ceramic assemblage at the Riser site, accounting for 95 percent of the decorated sherds (Table 2). Furthermore, more than 81 percent of the rims from decorated vessels are from utility ware vessels. The most common decorative method in the sherds from the site is brushing, as 38 percent of the sherds have brushing, either as the sole decorative element or in combination with appliqued, incised, or punctated elements. The proportion of brushing in the assemblage suggests that much of the ceramic assemblage may be the product of a post-A.D. 1200 Middle or Late Caddo period occupation, as vessels with brushed decorations become more common after that time in Angelina River basin 
Caddo sites. These brushed sherds are likely from Bullard Brushed vessels, except the brushed-appliqued sherd may be from a Pease Brushed-Incised jar.

Table 2. Decorated sherds from the Riser site (41NA20).

\begin{tabular}{l}
$\begin{array}{l}\text { Decorative method/ } \\
\text { decorative element }\end{array}$ \\
\hline
\end{tabular}

Utility Ware

\section{Appliqued}

curvilinear appliqued ridges

straight appliqued fillet

$-$

$-$

\section{Brushed}

horizontal brushing marks

parallel brushing marks

\section{Brushed-Appliqued}

diagonal brushed-straight appliqued fillet

\section{Brushed-Incised}

parallel brushed and overlying diagonal incised lines

\section{Brushed-Punctated}

parallel brushed-tool punctated rows

through the brushing

\section{Incised}

cross-hatched lines

diagonal lines, R-L

diagonal lines

diagonal opposed lines

opposed lines

parallel lines

straight line

\section{Incised-Punctated}

crescent-shaped fingernail punctated rows between horizontal incised lines

diagonal lines, R-L and cane punctated zone

in incised triangle el.

horizontal line above incised triangle filled

with circular punctates

incised triangle above row of circular punctates

straight line and adjacent cane punctated zone

straight line and adjacent fingernail punctated zone
3

$-$

23

1

1

$-$

$-$

2

$-$

1

$-$

$-$

$-$

1

1

1

1

1

$\begin{array}{lll}- & 1 & 1\end{array}$

$\begin{array}{lll}- & 1 & 1\end{array}$

$\begin{array}{lll}- & 1 & 1\end{array}$ 
Table 2. Decorated sherds from the Riser site (41NA20), cont.

\begin{tabular}{lccc}
\hline $\begin{array}{l}\text { Decorative method/ } \\
\text { decorative element }\end{array}$ & Rim & Body & N \\
\hline $\begin{array}{l}\text { Pinched } \\
\text { parallel pinched ridges }\end{array}$ & - & 1 & 1 \\
$\begin{array}{l}\text { Punctated } \\
\text { fingernail punctated rows }\end{array}$ & - & 7 & 7 \\
tool punctated rows & - & 11 & 11 \\
Fine Ware & & & \\
Engraved & - & 1 & 2 \\
curvilinear lines, closely-spaced & & - & 1 \\
diagonal lines, R-L & - & 1 & 76 \\
\hline opposed lines & - & 65 & \\
\hline Totals & 11 & & \\
\hline
\end{tabular}

$\mathrm{R}-\mathrm{L}=$ right to left; incised or engraved lines begin at the right at the top of the rim and end at the left at the bottom of the rim

Other common decorative methods in the utility ware sherds from the Riser site include rows of punctations (24 percent), either fingernail or tool punctations, and incised elements (21 percent) (see Table 2). The latter include rims from Maydelle Incised vessels with diagonal and diagonal opposed incised lines on the vessel rim (Figure 3b).

The incised-punctated sherds from the Riser site are a diverse lot. One rim is from a pre-A.D. 1300 Weches Fingernail Impressed, var. Weches vessel (see Figure 3a; Stokes and Woodring 1981). Two other rim and body sherds may be from pre-A.D. 1300 Crockett Curvilinear Incised or Pennington Punctated-Incised vessels as they have incised triangular zones or panels filled with rows of cane punctations (see Figure 3cd). The one sherd with pinched ridges is from a Killough Pinched vessel.

The four fine ware sherds from the Riser site have both curvilinear and geometric decorative elements (i.e., diagonal or opposed lines) (see Table 2). None of the fine ware sherds can be identified as a specific East Texas fine ware type.

\section{NA22, Iron Rock Site}

The Iron Rock site is on an upland ridge on the west side of Bayou Loco. It is estimated to cover about 5-10 acres of the landform. Tom Mayhew excavated a test pit at the site in March 1972, and UT archaeologists obtained surface collections from three areas on the site (A-C). In 1975, UT archaeologists excavated a number of backhoe trenches at the site as well as nine test pits. In April 2011, Bo Nelson and Mark Walters revisited the site as part of a selected examination of the Lake Nacogdoches shoreline by Tom Middlebrook, George Avery, and others (Jackson et al. 2012:198).

A notable find from the Iron Rock site is a ca. A.D. 1700-1740 European-made glass bead. The large opaque white bead $(7.7 \mathrm{~mm}$ in diameter) is barrel to oval-shaped, and can be classified as Type IIa15 in the Kidd and Kidd (1970) scheme. This is a common bead form in Historic Caddo sites in East Texas. 


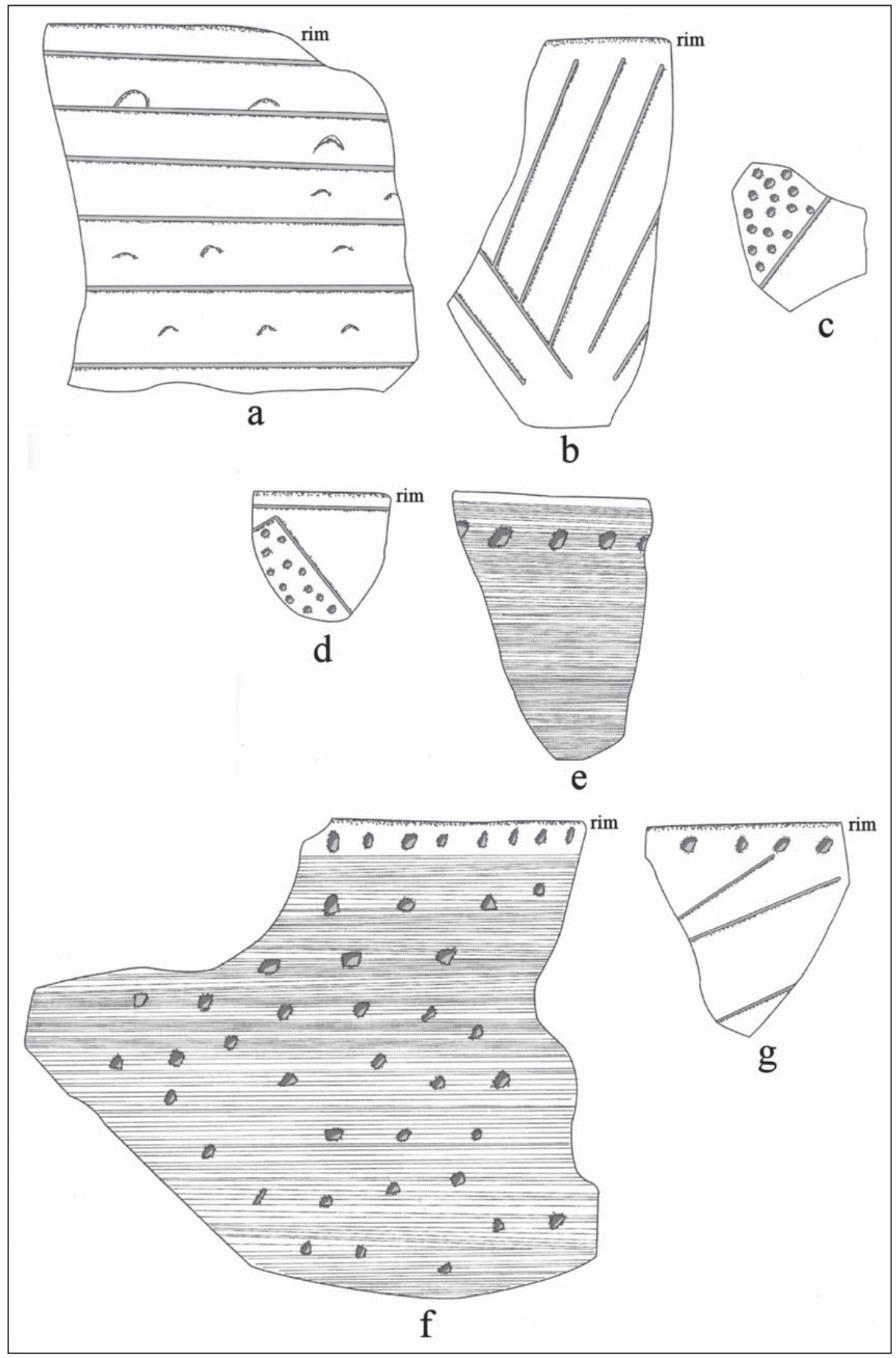

Figure 3. Selected decorative elements in the utility ware sherds from Bayou Loco sites: a-d, 41NA20; e-f, 41NA22; g, 41NA24. 
There are 67 sherds in the collections from the Iron Rock site examined for this study (a much larger assemblage of Caddo sherds from the 1975 surface collections and test pits remains to be studied in detail). Two of the sherds are body sherds from Woodland period Goose Creek Plain, var. unspecified vessels. The other 65 sherds, as well as a large rim vessel section, are from an ancestral Caddo occupation at the site.

The Caddo ceramic sherd assemblage from the Iron Rock site is comprised of both grog-tempered $(n=39,60$ percent $)$ and bone-tempered $(n=26,40$ percent) vessels. Forty-nine of the sherds are from utility ware $(n=47)$ and fine ware $(n=2)$ vessels (Table 3$)$. All of the utility ware vessels have brushing marks on the rims and/or the vessel bodies: 85 percent simply have brushing marks and are from Bullard Brushed vessels, and another 15 percent have brushing marks in combination with appliqued, incised, and punctated decorative elements (see Figure 3e-f). The very high proportion of brushed sherds in the utility wares, taken together with the recovery of an early 18th century European glass bead from the site, clearly indicates that (1) the Iron Rock site was occupied by Caddo peoples during the Historic Caddo period, and (2) that it was part of the community of Caddo peoples that lived along Bayou Loco during the period of early European contact and settlement (cf. Jackson et al. 2012).

Table 3. Decorated sherds from the Iron Rock site (41NA22).

\begin{tabular}{llll}
\hline $\begin{array}{l}\text { Decorative method/ } \\
\text { decorative element }\end{array}$ & Rim & Body \\
\hline
\end{tabular}

Utility Ware

\section{Brushed}

diagonal brushing marks

horizontal brushing marks

opposed brushing marks

overlapping brushing marks

parallel brushing marks

\section{Brushed-Appliqued}

opposed brushed-straight appliqued fillet

parallel brushed-straight appliqued fillet

$\begin{array}{lrr}1 & - & 1 \\ 1 & - & 1 \\ - & 1 & 1 \\ - & 1 & 1 \\ - & 36 & 36\end{array}$

\section{Brushed-Incised}

parallel brushed-incised

\section{Brushed-Punctated}

diagonal brushed-tool punctated row under

1

the lip and pushed through the brushing

horizontal brushed with rows of tool punctates

1

\section{(1)}

\section{(1)} 1 36 pushed through the brushing parallel brushed-tool punctated row through the brushing

Fine Ware

Engraved straight line $-$ 2 2 
The one vessel section from the Iron Rock site is represented by three conjoined rim sherds from a grog-tempered Poynor Engraved, var. unspecified carinated bowl. The folded over lip has a row of tool punctations on it, and the upper part of the rim panel is plain. The lower part has a single horizontal engraved line at the top, along with a series of large cross-hatched engraved brackets (Figure 4), similar to what is seen on Poynor Engraved, var. Hood vessels (see Perttula 2011:Figure 6-64e). Where the Iron Rock vessel section differs from this recognized variety of Poynor Engraved is in the hatched pendant triangles between the cross-hatched engraved brackets.

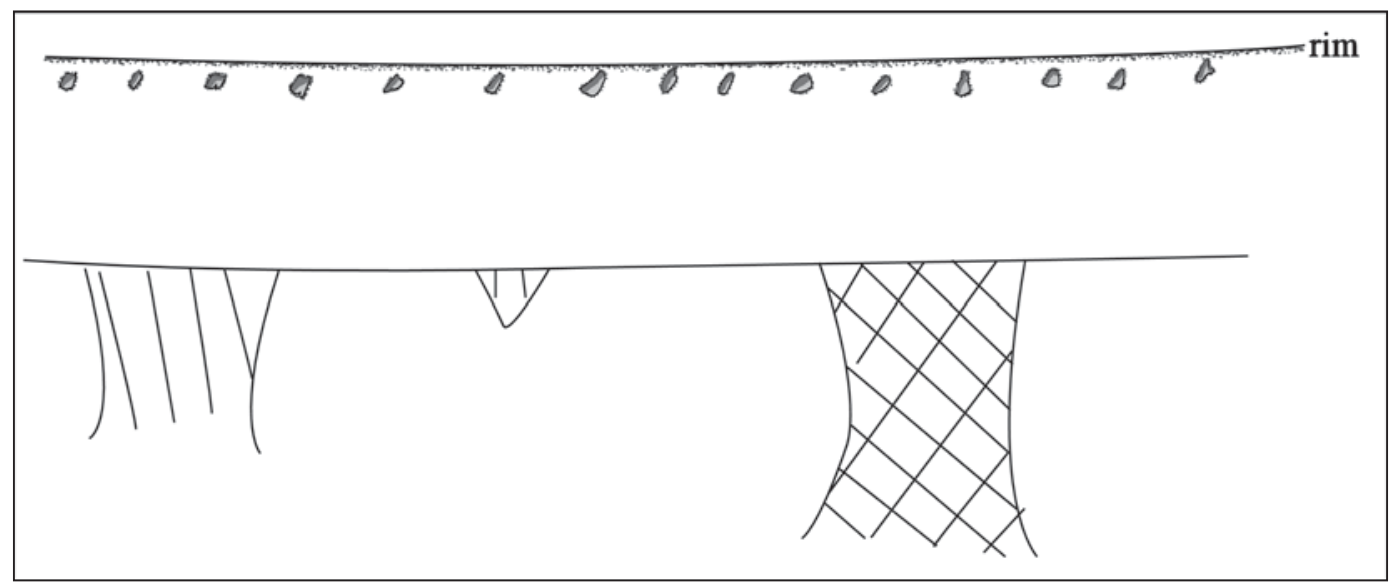

Figure 4. Decorative motif on engraved-punctated vessel from the Iron Rock site (41NA22).

The work at the Iron Rock site recovered 25 arrow points or arrow point fragments and two arrow point preforms. Thirteen of the points are Perdiz, the principal arrow point type in Late and Historic Caddo sites in the Angelina River basin (see Girard 1995) and one is a Friley type. The Friley is one of the earliest arrow point types in East Texas sites, occurring as early as ca. A.D. 700-800 in the latter part of the Woodland period (Shafer and Walters 2010). The arrow points, fragments, and preforms are made on locally available petrified wood $(n=19)$, quartzite $(n=4)$, and red chert $(n=2)$, as well as from non-local dark gray $(n=1)$ and dark grayish-brown $(\mathrm{n}=1)$ chert.

\section{NA24, Electric Site}

This small site (ca. 0.25 acres) is on an upland ridge overlooking Yellow Bank Creek, an eastward-flowing tributary of Bayou Loco. UT archaeologists collected a small number of artifacts from the site surface in July 1972. In April 2011, Bo Nelson and Mark Walters revisited the site as part of a selected examination of the Lake Nacogdoches shoreline by Tom Middlebrook, George Avery, and others (Jackson et al. 2012:198).

The artifacts from the Electric site are from an ancestral Caddo component that likely dates after ca. A.D. 1300 . This component is marked by 10 ceramic sherds from plain ware $(n=7)$ and utility ware $(n=3)$ vessels that are tempered with grog $(80$ percent) and bone $(20$ percent $)$. The three decorated sherds in the small ceramic assemblage include two body sherds with parallel brushing marks and a probable Maydelle Incised rim sherd (see Figure $3 \mathrm{~g}$ ). This rim sherd has a row of tool punctations below the vessel lip and sets of right-to-left diagonal incised lines (see Suhm and Jelks 1962:103).

\section{NA26}

Site 41NA26 is on a small (1.0 acres) natural alluvial rise at the edge of the Bayou Loco floodplain and east of Bayou Loco itself. It is not far south of the Deshazo site (Story 1982, 1995). 
There is a Woodland period component at the site, based on the recovery of two petrified wood Gary dart points, a petrified wood Kent dart point, and one body sherd from a Goose Creek Plain, var. unspecified body sherd. The rest of the TARL collection is associated with an ancestral Caddo occupation, probably one that took place during Historic Caddo period (ca. post-A.D. 1680) times.

The lithic artifacts that are part of the Caddo component at 41NA26 include a gray chert Perdiz arrow point and a flake from the poll end of a quartzitic sandstone celt. There are 18 sherds from tempered vessels in the site collection: 83 percent from grog-tempered vessels and 17 percent from bone-tempered vessels. Thirteen of the sherds are decorated: 12 body sherds with parallel brushing marks. The other is an engraved rim from a Patton Engraved, var. unspecified vessel with linear tick marks on a horizontal engraved line under the lip as well as diagonal lines on the rim panel (see Figure 2c). On the basis of the one Patton Engraved rim sherd, the Caddo occupation at 41NA26 took place during Historic Caddo times.

\section{NA29}

This site is on a small (0.5 acres) alluvial terrace at the edge of the Bayou Loco floodplain, on the east side of Bayou Loco itself. UT archaeologists obtained a small collection of artifacts from the surface of the site in July 1972.

The TARL collection from 41NA29 includes a few artifacts from a Woodland period (ca. 2500-1150 years B.P.) occupation, namely two body sherds from Goose Creek Plain, var. unspecified vessels. The remaining 43 sherds are from grog- ( $n=32,74$ percent) and bone-tempered ( $n=11,26$ percent) Caddo vessels. A total of 26 sherds have decorative elements, including 25 sherds from utility ware vessels: 20 parallel brushed sherds; two body sherds with parallel or straight incised lines; and brushed-punctated $(n=1)$ and brushed-appliqued $(n=2)$ sherds. The brushed-punctated sherd is from a Bullard Brushed vessel that has parallel brushing marks on the vessel body and a row of tool punctations pushed through the brushing. Both brushed-appliqued body sherds have a straight appliqued fillet with parallel brushing marks on either side of the fillet; the fillet likely created vertical panels on the body of a utility ware jar that were filled with vertical brushing marks.

The one fine ware sherd from 41NA29 is a rim sherd from a King Engraved carinated bowl (see Figure 2d). The rim has a zone of closely-spaced cross-hatched lines, and the vessel body has horizontal brushing marks. King Engraved is an Historic Caddo Allen phase fine ware found in ceramic assemblages in the Angelina River basin. Decorative elements include cross-hatched engraved zones, either in panels, in panel dividers, or in large bands oriented in several directions on the rim (Marceaux 2011:154). The recovery of the King Engraved sherd from 41NA29 suggests it is part of the post-A.D. 1680 Historic Caddo community centered at the Deshazo site on Bayou Loco (Good 1982; Story and Creel 1982).

\section{SUMMARY AND CONCLUSIONS}

The sites along Bayou Loco discussed in this article were recorded and investigated as part of the archaeological work done in 1972 and 1975 before the construction of Lake Nacogdoches. They are situated on various landforms, either alluvial or upland ridges, in or in proximity to the floodplain of Bayou Loco, a southward-flowing tributary to the Angelina River in western Nacogdoches County, Texas.

The archaeological material culture remains recovered (either in surface collections or test pits) from these six Bayou Loco sites indicate that their earliest use was during the Late Archaic at the Pleasant Hill site (41NA19). Five of the six sites evidence settlement during the Woodland period (ca. 2500-1150 years B.P.), namely Gary or Kent dart points and rim and body sherds from Goose Creek Plain, var. unspecified sandy paste vessels. All of the Bayou Loco sites were occupied by ancestral Caddo peoples, beginning with 
a pre-A.D. 1300 and later Middle Caddo period settlement (with 38 percent of the decorated sherds in the assemblage having brushing marks on them) at the Riser site (41NA20); Late Caddo period settlements at the Pleasant Hill (41NA19) and Electric (41NA24) sites (with 55-67 percent of the decorated sherds in their assemblages having brushing marks on them); and post-A.D. 1680 Historic Caddo (Hasinai Caddo) settlements at the Iron Rock (41NA22), 41NA26, and 41NA29 sites. The sherd assemblages at these sites have between 88-100 percent of the decorated sherds with brushing marks on them. Diagnostic Historic Caddo fine wares from these sites include Patton Engraved and King Engraved, the chipped stone tools are dominated by Perdiz arrow points made from local lithic raw materials, and an early $18^{\text {th }}$ century European glass bead was found at the Iron Rock site. These sites are part of the post-A.D. 1680 Historic Caddo community centered at the Deshazo site on Bayou Loco (Good 1982; Story and Creel 1982).

\section{ACKNOWLEDGMENTS}

I thank Jonathan Jarvis, once again, for facilitating access to the records and collections from these Bayou Loco sites held by TARL. Lance Trask prepared the figures in this article.

\section{REFERENCES CITED}

Ellis, L. W.

2013 Woodland Ceramics in East Texas and a Case Study of Mill Creek Culture Ceramics. Bulletin of the Texas Archeological Society 84:137-180.

Girard, J. S.

1995 The Chipped Stone Collection: Technological, Functional, and Typological Analyses. In The Deshazo Site, Nacogdoches County, Texas, Volume 2: Artifacts of Native Manufacture, edited by D. A. Story, pp. 33-156. Studies in Archeology 21. Texas Archeological Research Laboratory, The University of Texas at Austin.

Good, C. E.

1982 Analysis of Structures, Burials, and Other Cultural Features. In The Deshazo Site, Nacogdoches County, Texas, Volume 1, edited by D. A. Story, pp. 51-110. Texas Antiquities Permit Series 7. Texas Antiquities Committee, Austin.

Jackson, M. K., T. Middlebrook, G. Avery, H. Shafer, and B. Meissner

2012 Trade and Cultural Interaction along El Camino Real de los Tejas During the Spanish Colonial and Republic Periods in Nacogdoches County, Texas. 2 Vols. Nine Flags Museum, Nacogdoches.

Kenmotsu, N. A

1992 The Mayhew Site: A Possible Hasinai Farmstead, Nacogdoches County, Texas. Bulletin of the Texas Archeological Society 63:135-174.

Kidd, K. E. and M. A. Kidd

1970 A Classification System for Glass Beads for the Use of Field Archaeologists. Occasional Papers in Archaeology and History No. 1, pp. 45-89. National Historic Sites Service, National and Historic Parks Branch, Department of Indian Affairs and Northern Development, Ottawa, Ontario.

Marceaux, P.S.

2011 The Archaeology and Ethnohistory of the Hasinai Caddo: Material Culture and the Course of European Contact. Ph.D. dissertation, Department of Anthropology, The University of Texas at Austin. 
Perttula, T. K.

2011 The Ceramic Artifacts from the Lang Pasture Site (41AN38) and the Place of the Site within an Upper Neches River Basin Caddo Ceramic Tradition. In Archeological Investigations at the Lang Pasture Site (41AN38) in the Upper Neches River Basin of East Texas, assembled and edited by T. K. Perttula, D. B. Kelley, and R. A. Ricklis, pp. 145-320. Archeological Studies Program Report No. 129, Texas Department of Transportation, Environmental Affairs Division, Austin.

2013 Caddo Ceramics in East Texas. Bulletin of the Texas Archeological Society 84:181-212.

Prewitt, E. R, J. W. Clark, Jr., and D. S. Dibble

1972 An Assessment of the Archeological and Historical Resources of the Bayou Loco Reservoir Area, Nacogdoches County, Texas. Research Report 11. Texas Archeological Salvage Project, The University of Texas at Austin.

Shafer, H. J. and M. Walters

2010 The Browning Site (41SM195A) Lithics: Considering Patterns of Identity and Interaction through Lithic Analysis. Bulletin of the Texas Archeological Society 81:127-151.

Stokes, J. and J. Woodring

1981 Native-Made Artifacts of Clay. In Archeological Investigations at the George C. Davis Site, Cherokee County, Texas: Summers of 1979 and 1980, edited by D. A. Story, pp. 135-238. Occasional Paper No. 1. Texas Archeological Research Laboratory, The University of Texas at Austin.

Story, D. A. (editor)

1982 The Deshazo Site, Nacogdoches County, Texas, Vol. 1: The Site, Its Setting, Investigations, Cultural Features, Artifacts of Non-Native Manufacture, and Subsistence Remains. Texas Antiquities Permit Series No. 7. Texas Antiquities Committee, Austin.

1995 The Deshazo Site, Nacogdoches County, Texas, Vol. 2: Artifacts of Native Manufacture. Studies in Archeology 21. Texas Archeological Research Laboratory, The University of Texas at Austin.

Story, D. A. and D. G. Creel

1982 The Cultural Setting. In The Deshazo Site, Nacogdoches County, Texas, Vol. 1, edited by D. A. Story, pp. 20-34. Texas Antiquities Permit Series No. 7. Texas Antiquities Committee, Austin.

Suhm, D. A. and E. B. Jelks (editors)

1962 Handbook of Texas Archeology: Type Descriptions. Special Publication No. 1, Texas Archeological Society, and Bulletin No. 4, Texas Memorial Museum, Austin. Reprinted in 2009, Gustav's Library, Davenport, Iowa. 